\title{
Innovation and reciprocity in applied linguistics
}

\begin{abstract}
Author:
Albert Weideman ${ }^{1,2}$

Affiliations:

${ }^{1}$ Department of Linguistics and Language Practice,

University of the Free State,

South Africa
\end{abstract}

${ }^{2}$ Inter-Institutional Centre fo Language Development and

Assessment (ICELDA),

South Africa

\section{Correspondence to:}

Albert Weideman

Email:

weidemanaj@ufs.ac.za

Postal address:

Stef Coetzee Building 227,

University of the Free State,

Nelson Mandela Avenue,

Park West, Bloemfontein

9301, South Africa

Dates:

Received: 05 Aug. 2013

Accepted: 10 Oct. 2013

Published: 20 Mar. 2014

How to cite this article:

Weideman, A., 2014,

'Innovation and reciprocity in applied linguistics', Literator

35(1), Art. \#1074, 10 pages.

http://dx.doi.org/10.4102/lit.

v35i1.1074

Note:

This is the reworked text of a keynote address to the 2013 Joint Annual Conference of the South African Association for Language Teaching (SAALT), the Southern African Applied Linguistics Association (SAALA) and the Linguistics Society of Southern Africa (LSSA) held in Stellenbosch (South Africa), on 01 July 2013.

\section{Copyright:}

(C) 2014. The Authors.

Licensee: AOSIS

OpenJournals. This work

is licensed under the

Creative Commons

Attribution License.

\section{Read online:}

Applied linguistics is a discipline of design: it solves language problems by suggesting a plan, or blueprint, to handle them. These designs are sometimes promoted as highly innovative. Yet, are innovative language courses and tests in all respects truly new? This article will argue that most historically significant turning points in applied linguistic design demonstrate continuity with previously designed solutions. This was so for communicative teaching as well as for audio-lingualism. In testing, both interactive designs and socially responsible concerns have built on the past. Like innovation, reciprocity in design in applied linguistics is a foundational issue. How much reciprocity is there in the realms of language testing, language course design and language policy making? Why do we not explicitly check whether the design of a course should be as responsibly and carefully done as a test? How can we learn more from language policy development about making tests more accessible and accountable? What can test designers learn from course developers about specificity? There are many useful questions that we never seem to ask. The article will look across different levels of applied linguistic artefacts (language courses, language tests and language policies) at how we can enrich the principles of responsible design. We can continue to be surprised by innovation in the designed solutions that our profession provides, but we should also work on our understanding of what constitutes a responsible design framework. That foundation enables us to evaluate both the fleeting and the enduring in the new.

Innovasie en wederkerigheid in die toegepaste taalkunde. Toegepaste taalkunde is ' $n$ ontwerpdissipline: dit los taalprobleme op deur'n plan of bloudruk vir die hantering daarvan voor te stel. Hierdie ontwerpe word soms as hoogs vernuwend aangemerk. Is innoverende taalkursusse en -toetse egter in alle opsigte regtig nuut? Hierdie artikel argumenteer dat histories-betekenisvolle draaipunte in toegepaste taalkundige ontwerpe ' $n$ beduidende mate van kontinuïteit met vorige ontwerpe toon. Dit was die geval met kommunikatiewe taalonderrig, en selfs vir vroeëre innovasies soos die oudio-lingualisme. Ook in taaltoetsing bou beide interaktiewe en meer sosiaal-verantwoordbare ontwerpe op die verlede. Soos met vernuwing, is die idee van wederkerigheid in toegepaste taalkundige ontwerpe ' $n$ grondslagkwessie. Hoeveel wederkerigheid bestaan daar op die gebiede van taaltoetsing, taalkursusontwerp en taalbeleidsformulering? Hoekom kyk ons nie spesifiek na of die ontwerp van 'n kursus net so verantwoordelik en noukeurig gedoen word as dié van 'n toets nie? Wat kan ons leer by taalbeleidsformulering as ons toetse meer toeganklik en verantwoordbaar wil maak? Wat kan toetsontwerpers by kursusontwikkelaars oor spesifisiteit leer? Daar bestaan talle nuttige vrae wat ons skynbaar nooit vra nie. Hierdie artikel oorweeg hoe, deur oor verskillende vlakke van toegepaste taalkundige artefakte (taalkursusse, taaltoetse en taalbeleide) heen te kyk, ons die beginsels van verantwoordelike ontwerp kan verryk. Ons wil graag verras word deur innovering in die ontwerpe wat ons professie aanbied, maar ons moet terselfdertyd werk aan ons begrip van 'n verantwoordelike ontwerpraamwerk. So ' $n$ vertrekpunt bied ons 'n maatstaf om die vlietende en die standhoudende in nuwe ontwerpe mee te beoordeel.

\section{Introduction}

\section{Is history destiny?}

Will language teaching survive as a profession? Not for the first time in its modern history is the combination of new technological instruments and a belief in scientific progress yielding forecasts of its imminent demise. A recent look into the future (Greene 2012:75) confidently predicts that language teaching may by 2050 become obsolete, since so many new technologies will make instant translation possible that there will be no more demand for learning a foreign language. In a similar vein, the article 'Has the ideas machine broken down' (The Economist 2013) makes the point that new technologies and their global reach may well begin to threaten not only jobs that require low levels of skill, but also ones requiring higher skills levels: 
Pattern-recognition software is increasingly good at performing the tasks of entry-level lawyers, scanning thousands of legal documents for relevant passages. Algorithms are used to write basic newspaper articles on sporting outcomes and financial reports. In time, they may move to analysis ... (The Economist 2013:22)

Whilst the threats to aspiring lawyers and journalists may be new, it is certainly not the first time in the history of the design of language instruction that we are faced with a prediction that forecasts its disappearance, based on advances in technology.

The theme of innovation in applied linguistics is irrevocably tied to its historical origins in the mid-20th century endeavour to secure a rational, scientific basis for language teaching designs (Fries 1945; Lado 1964; Stevick 1971:2). Of course, applied linguistics has since that time gone much wider than that initial concern. Apart from the range of forensic, lexicographic, translation and language recognition as well as other work that it also encompasses, it has in addition become established as a distinct discipline. It has achieved this especially through three prominent subdisciplines that concern themselves with language designs and plans. These three, that deal with designed solutions for apparently intractable language problems, are language management, language instruction and language assessment. In this article I shall primarily be referring to the last two. The point that I wish to begin with, however, is that, given that historical starting point for the fledgling discipline, it is hardly surprising that the expectation was that science and theoretical analysis would assist us in finding the correct ways of designing these plans, be they language policies, language teaching methods, or language tests. Or to put it differently: applied linguistics as a discipline has an unashamedly modernist origin (Weideman 2013a, 2013c). It is an origin that was from the outset reinforced by the combination of 'scientific' or theoretical analysis with technology, and nowhere was this more in evidence than in the elaborate machinery for listening to, recording and monitoring speech that accompanied the audio-lingual method in the shape of 'language laboratories'. It is typical of a modernist bias, in fact, that no one readily objected to the use of the term 'laboratory' in this regard, though the machines in question were little more than sophisticated language drill and control devices. There was nothing going on in them that could remotely be associated with experimentation, but, at least for those of us who toiled in them some 40-50 years ago, the term 'laboratory' seemed to reinforce the strength our discipline derived from such a connection with both science and technology. Whilst technology offered the instructional intervention state of the art sound recording equipment, the theoretical insights of American structuralist linguistics and behaviourist psychology provided the 'scientific' basis for audio-lingualism. It was therefore uncritically accepted as a good development, since we were thought to be making 'scientific' headway. If one has to give an account of where the quest for innovation in applied linguistics derives from, one answer would therefore certainly have to be that early applied linguistics provided the discipline with the expectation that innovation would flow from the best theory, combined with advances in technology.

It is a historical fact, however, that this starting point has not endured. Not only did the critiques emanating from transformational-generative grammar fundamentally undermine the credibility of the behaviourist theory supposedly underlying audio-lingualism (cf. Carroll 1971), but empirical analyses (e.g. Lamendella 1979) had also begun to show its shortcomings as a language-teaching method. If we skip forward a few decades in the history of the discipline we see that by the late 20th century several forms of postmodernism had replaced modernist paradigms and the expectations the latter had brought to applied linguistics. It is only in the last two decades that a serious alternative to postmodernism itself has arisen (Weideman 2009b, 2011a, 2013a). What is important to note for the current discussion, however, is that under the sway of a postmodernist paradigm, the 'postmethod condition' (Kumaravadivelu 2003; Bell 2003) called off the search for the best method of language teaching quite a while ago. To its credit, a postmodernist design approach in applied linguistics, such as that outlined in Kumaravadivelu's (2003) work, much more realistically conceptualises improvement in terms of incremental design gains that are for the most part locally conceived as well as highly contextualised. In place of the search for a best method, we now have eclecticism of either refined or unrefined sorts.

Kumaravadivelu's (2003; 2006) milder version of what constitutes a postmodernist approach is not its only interpretation, however. We find a different and more radical answer when we consider its politically more acute interpretations and ask the question: What has happened to the expectation of innovation that marked the beginning of the discipline of applied linguistics? Then we are confronted by Pennycook's contention (1989:608; cf. also Pennycook 1994, $1999,2004)$ that, rather than presenting us with the results of steady, linear progress, reputedly innovative language teaching designs are merely a 'different configuration of the same basic options', and that the causes for change in language teaching are mainly the effects of the workings of social, political or ideological factors. If Pennycook's observation is true, innovation is impossible unless, perhaps, we subscribe to the politically radical alternative of finding the transformation of language teaching practices in continuous critical engagement with the forces that have shaped language education, and that for others have promised innovation. Our discipline is thus caught between technocracy and revolution.

The focus of this article will be less on proposing how innovation may be conceived in designs, and more on assessing the relative worth of previous and possible future design innovations against a conceptual framework for responsible applied linguistic designs. The aim of the article is therefore to show that, as an alternative for the technocratic and revolutionary directions within our discipline, we should seek principles for responsible course and test design. 
Of course, how we do so remains the challenge, and the examples presented below are offered as an illustration of that. It will be the thesis of this article that a good starting point is to begin with a conceptualisation of applied linguistics that remarkably is shared by modernist and postmodernist approaches alike: that it is a discipline concerned with design (Corder 1972; Cope \& Kalantzis 2000).

\section{Will eclecticism inspire innovation?}

If we do not quite wish to go along with the relativist interpretations of applied linguistics that characterise the politically more radical directions within the discipline referred to above, it may be that our preference is for a more or less refined kind of eclecticism. If we subscribe to a sophisticated form of eclecticism, we might hope that it will yield innovation and novelty in course and test design. So a valid question to ask in that case would be: Can eclecticism itself not perhaps be the sought-after principle of innovation in design? Whilst one of its initial results may be innovation, the irony of eclecticism is that it inevitably builds on the old. In time, especially in an unrefined adoption of eclecticism, it may in fact become an excuse for resisting change (Weideman 2001, 2002a; Weideman, Tesfamariam \& Shaalukeni 2003), and so undermine innovation.

The various types of eclectic combinations we find can be summarised in a matrix (Figure 1), in which an 'anything goes' style of accommodating whatever 'works' is contrasted with a principled, consistent and deliberate adoption of a plurality of methods and techniques, in combination with different motivations for the adoption of an eclectic approach (Weideman 2001). The first of such motivations may be the wish to avoid ideology; the second the desire to avoid having to change one's teaching; the third the inclination to embrace a moderate degree of change; and the fourth the firm intention to make deliberate and consistent changes to one's teaching. The desirable quadrant is obviously the fourth, that combines a principled combination with the firm intention to see the change through, whilst the third, in which the adoption is cautious but still deliberate, may also embody some (moderate) potential for innovation in language teaching.

Looked at from the angles of how resistant the individual language teacher is to change, and how coherent their approach is (Figure 2), it becomes clear that innovation is best served by having a highly coherent approach, combined with a low resistance to change.

In both characterisations, innovation is best served through deliberation and rationality in design. Put another way: to be a professional language teacher, one needs to know where one's methods derive from, as well as why their use can be justified. That postmodernism has declared the death of method is therefore doubly ironic. Firstly, by subscribing to a method of language teaching, a teacher may have been able to find and critically engage with the theoretical justification of that method, in linguistics or in learning theory. The method

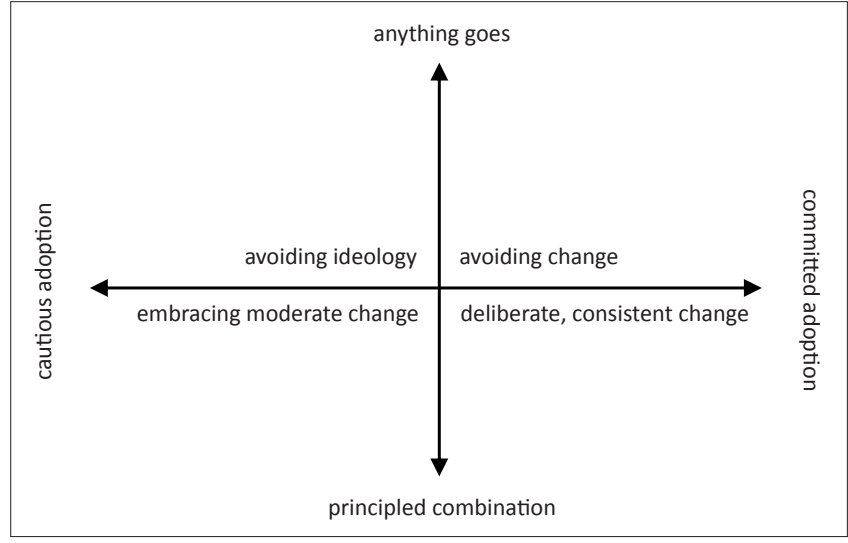

FIGURE 1: Different possible motivations in adopting an eclectic approach.

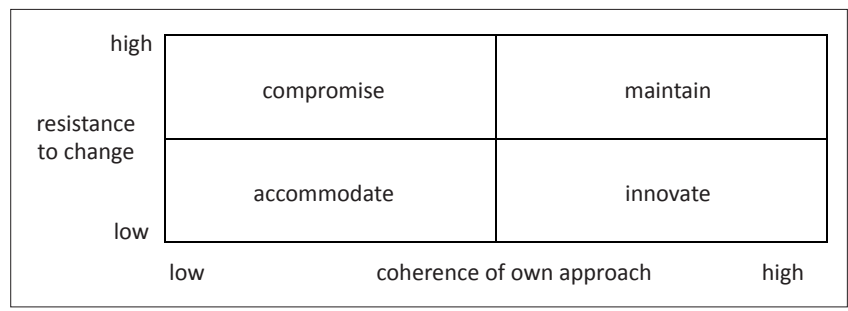

FIGURE 2: Potential for innovation.

might thus have provided a conceptual 'handle' to get to grips with the analytical undertow that supported it. To a certain extent, abandoning method deprives one of that kind of critical understanding. Secondly, before postmodernism declared the death of method on the basis of the reliance of method on conventional scientific and economic forces, some of the most innovative language teaching methods derived neither from mainstream, nor even from highly reputable theories. Good examples can be found amongst the fringe or peripheral language teaching methodologies, such as the Silent Way and Suggestopedia (and with the exception, perhaps, of Community Language Learning [CLL] with its Rogerian undertow). Yet each of them not only embodied a highly coherent approach, justifiable on its own terms, but they were also adopted more often than not by highly dedicated teachers: Stevick (1980; cf. see also 1971) provides as good an example as any of such an inspiring language educator. If one is looking for exotic techniques, these socalled humanistic methods provide an illustration of the revolutionary edge that they represent in language course design. Inspired in our own design work by such integrators of method as Stevick, for example in designing courses for beginners (Weideman \& Rousseau 1996), we included combinations of adult language learning techniques such as the Silent Way and CLL with communicative language teaching (CLT) and Natural Approach techniques, in a way that had never before been tried. To most, a method that was appropriate and intended for adult language teaching just could not be suitable for young learners of English as an additional language. Yet an external evaluation by one of the leading language experts of the day (Kroes 1991a, 1991b) found that the combination was highly successful, an opinion that was vindicated when the course that flowed from it was published by a highly reputable international publishing 
house. The integration in this case, however, was deliberate, committed and consistent, with a clear rationale in order to advance its adoption by reflective, professionally-inclined language teachers.

This discussion of what kind of eclecticism (deliberate and principled) will assist in committing oneself professionally to an innovation leads us to ask another question: How novel can language course design really be? In historical advances in any field, are spectacular leaps the norm, or are incremental improvements? Is the incremental innovation, as implied by Kumaravadivelu's (2003) suggestions, not perhaps the more realistic alternative? As I hope to show in the next section, for those with progressivist expectations, the history of language teaching is quite sobering on this point.

\section{Continuity in teaching approaches and methods}

The novelty in language course design referred to above is never new in all respects; as a rule, revolutionary or disruptive design, if not an impossibility, then remains at least an improbability. As a case in point, we may consider the move towards a communicative approach to language teaching that began in the mid-1970s, gathered quite a bit of momentum in the early 1980s, and was (apparently) well established by the middle of the 1980s.

What made CLT different from what preceded it? First, was that it took its inspiration from a broader view of language; it adopted a functional rather than a structural perspective on language. On this depended the first of many misinterpretations as to how language should be taught as well. Where before, we would have taught a piece of grammar, say the present continuous tense, we now had to teach functions, such as the act of agreeing. The piecemeal method of instruction was simply transferred by some teachers to the supposedly new approach, and this created an immediate (though unjustifiable) continuity with the old. That this interpretation was theoretically at odds with CLT, and could therefore not be justified with reference to the theoretical underpinnings of the new approach, is a clear indication that pedagogical practice always takes precedence over theoretical considerations, a point that will be further explained below.

A second respect in which CLT was novel was that, again inspired by a broader perspective on language, discourse and text, it took another look at the so-called 'skills' identified by the methods preceding it, and chose to focus rather on the media (telephone, face to face, print, etc.) one uses and the communicative roles (interviewer, information-seeker, presenter, author of specialised text) involved. Once more, most teachers, and at times also syllabi and course designers who wanted to implement CLT, stuck firmly with the divisions between 'listening', 'speaking', 'reading' and 'writing' - the skills that had been at the basis of language course design through the grammar-translation and direct methods in the last part of the 19th and the first half of the 20th century, and that had been 'scientifically' confirmed and reified by the behaviourist justifications for the audio-lingual method in the second half of the last century. Even today, in curriculum documents such as the curricula not only for English Home Language (Department of Basic Education [DBE] 2011a), but also for others, one finds an ambivalent commitment both to CLT and to teaching 'structures' and separate skills. That this curriculum also calls for their 'integration' merely confirms the embarrassment: in the view of language associated with CLT they cannot in the first instance be separated (for a full discussion, cf. Weideman 2013a; see also Kumaravadivelu 2003:226; Bachman \& Palmer 1996:75f.; Weideman \& Van Dyk in press:Introduction)

On both counts, what might have been innovations are undermined either by misinterpretation or lack of deliberation, of not thinking through the design implications of the new perspective. To imply therefore, as Heugh (2013) does, that it is the approach that is somehow undesirable because of its geographical origin (north instead of south), its purported dependence on wealth, or the social class of the learners exposed to it, is to misrepresent the case. As Heugh (2013:15) correctly observes, there is no administrative and intellectual support for it, 'hardly anyone in the system understands what it entails, or how it ought to be used by teachers in the classroom', and 'the approach is misunderstood to mean that the focus of language teaching is on spoken competence rather than on reading and writing.' Given this level of misunderstanding, surely the best of approaches would be unlikely to succeed? To blame the approach when all the other ingredients that reasonably had to accompany its introduction, implementation and maintenance are missing can never be a responsible conclusion. In any event, the suggestion by Heugh (2013:15) that an alternative approach should ensure 'awareness of multiple genres of text' is exactly what the approach she contests in the South African case prescribes, as even the most cursory examination of the curriculum and assessment policy statement (CAPS) (cf. DBE 2011a, 2011b) would reveal.

What should never be underestimated, however, is the historical continuity in the technical designs of solutions that are introduced. That continuity in design lies behind most of the case studies of contexts that have been resistant to change and innovation in language teaching, both in Africa and elsewhere (cf. Karavas-Doukas 1996; Weideman 2002a; Weideman, Tesfamariam \& Shaalukeni 2003). So, for example, in designing tests of the ability to handle academic discourse, such as those developed by the Inter-Institutional Centre for Language Development and Assessment (ICELDA) (see ICELDA 2013), we find an instance of a skills-neutral approach that is consciously and deliberately undertaken, yet potentially neither intelligible nor relevant to those who wish rather to see it developing tests of listening, speaking, reading and writing, in the behaviourist mode.

A real novelty in CLT that is often overlooked is its reliance on an information gap technique, which causes the language produced in communicatively-oriented classrooms to be unpredictable. One may well speculate that it is that unpredictability that puts off those whose own language 
capacity is insufficient for the task of teaching it. The fear of the unknown is a strong deterrent of innovation.

Apart from the misunderstandings of CLT, however, there is also a kind of technical continuity in its designs with what went before that is inherent in the techniques used. Thus, for example, if the litmus test for the implementation of CLT is the use of an information gap technique, we may find such techniques employed not only in pairs of language learners swapping information, but also in role plays, games and in total physical response (TPR) activities. But in all of these role plays, games and verbal instructions from the teacher - we have language teaching techniques that are associated with an earlier method, the Direct Method, in which a teacher, using 'realia', might instruct learners (as in TPR) to do certain actions. There is a difference, it is true, in that in the TPR classroom the non-threatening atmosphere associated with the Natural Approach (Krashen \& Terrell 1983) makes nonverbal responses demonstrating understanding sufficient, whereas in the Direct Method classroom the teacher, whilst firmly controlling the language, would follow up the instruction ('James, walk to the door!') with an immediate question: 'What is James doing?', which in its turn would demand an immediate answer from the class or from an individual learner. But the similarity is there for everyone to observe.

When one looks further back into the history of language teaching designs as they were embodied in various successive methods, one also finds a remarkable continuity. In line with the aesthetically driven language instruction of the late 19th century, the grammar translation method emphasised reading (to appreciate the canonical literature) and writing (understood as the composition of extended prose). This was apparently overturned when, under the influence of Gestalt theory, the Direct Method in the early part of the 20th century emphasised the other two 'skills', listening and speaking. Yet it did not take long - in fact one might speculate that it became inevitable - for the next method on the horizon, the audio-lingual, to come forward with the more comprehensive solution: Emphasise all four 'skills', listening, speaking, reading and writing, as if they are components of the overall language habit that according to behaviourist theory should be developed. It was nothing less, therefore, than an eclectic solution to a design quandary that had been many years in the making (Weideman 2002b). If one looks at the influences on CLT, or the movement to take ourselves beyond method, discussed above, it was not the last time that such a solution would be taken up. The point, however, is that such deliberate continuity in design is and remains a strong influence. Our designed solutions align more with the old and the familiar than with what is genuinely new.

\section{Continuity in the design of language assessments}

If CLT is not limited to speaking, as we noted above, then surely testing communicative language ability cannot be restricted to testing oral proficiency either. Communication implies interaction amongst two or more individuals, and this interaction may even be displaced (non-simultaneous) and remote, depending on the communicative medium. In fact, interaction with academic texts is what is most commonly and justifiably thought to constitute the appropriate source that provides material for tests of academic literacy. It is incontestable, however, that in making tests of academic literacy that proceed from the underlying cognitive processes (comparing, categorising, contrasting, inferencing, extrapolating and the like) that are reflected lingually in functions (originally mistakenly called 'speech' acts as if they existed only in the spoken form of the language) such as distinguishing, defining, explaining, illustrating, exemplifying, concluding and so on, we have not only found a novel way of assessing competence, but one that relies heavily on the past. With very few exceptions the questions in tests of academic literacy resemble those of earlier test designs. Their design gains, for example in the case of adaptations of cloze procedure (Van Dyk \& Weideman 2004), are incremental rather than revolutionary, as in the following:

In the following, you have to indicate the possible place where a word may have been deleted, and which word belongs there. Here are two examples:

Charles Goodyear (1800-1860) invented the vulcanization of rubber when he was experimenting by heating a mixture of rubber and sulphur. The Goodyear story is one of either pure luck or careful research, but both are debatable. Goodyear insisted that it was [i ] the [ii], though [iii] many [iv] contemporaneous [i] accounts [ii] indicate [iii] the [iv]

Where has the word been deleted?

A. At position (i).

B. At position (ii).

C. At position (iii).

D. At position (iv).

Which word has been left out here?

A. indeed

B. very

C. former

D. historically

Where has the word been deleted?

A. At position (i).

B. At position (ii).

C. At position (iii).

D. At position (iv).

Which word has been left out here?

A. historical

B. latter

C. now

D. incontrovertibly

(Adapted from Weideman \& Van Dyk in press)

This is recognisably cloze procedure, but the adaptation is such that it overcomes the logistical constraints associated with marking the answers by hand, and adds more dimensions to what may otherwise be another humdrum testing technique; that of testing not only textuality, but potentially also grammatical relations as well as (in some 
cases) communicative function. What is more, the format was not conceived by the designers of the tests who currently employ them to good effect; they derive from adaptations and modifications to a test task type of earlier South African tests of academic literacy. As the Schumpeter (2012:60) column 'Pretty profitable parrots' correctly observes, copying and imitation are much more prevalent (and successful) than innovation; nobody remembers White Castle ${ }^{\circledR}$, copied by McDonalds ${ }^{\circledR}$, or $\mathrm{Chux}^{\circledR}$, that conceded to Pampers ${ }^{\circledR}$. This echoes the research of Shenkar (2010), who notes that the Chery QQ imitation of the Chev Spark mini car came out within a year of the original, and that is now outselling the Chev sixfold. Nor is this limited to industrial and technical innovation: in investigating breakthroughs in science, Shenkar (2010:1) also found in a good eight disciplines, 'ranging from history to neuroscience ... imitation to be a primary source of progress.' The critical point, however, is that 'good imitation is difficult and requires intelligence and imagination.' To copy is not enough, therefore: an imaginative adjustment needs to be made to the design to be truly effective. Both opinions cited here make it clear, however, that adaptation and imaginative modifications in design are today the norm rather than the exception. The modification of the staid way of using cloze procedure to assess language ability through this 'Grammar and text relations' subtest provides an example of how the humdrum and the conventional can be imaginatively altered and re-employed.

Where questions in these tests do constitute innovation, it is innovation that often is necessary as a result of logistical constraints. In at least two South African undergraduate tests of academic literacy, the administration and marking time available, as well as sheer numbers of test takers, necessitate the employment of a multiple choice format of question. How to test language subtleties such as metaphoric and idiomatic usage and irony in that format is a challenge to the imagination and technical ability of test designers, as is the ability to compare text with text, or assess the control of communicative function, referred to above. Since all of thesemetaphoric usage, text comparison, and the comprehensibility of language functions - are essential components of the construct, imaginative ways have been found to assess the ability of a candidate in every one of them. The novelty lies in the newly-defined component of academic literacy that is being assessed, the technical continuity in the conventional format in which the assessment is accomplished.

Similarly, in seeking accountability for those designs (Rambiritch 2012; Weideman 2003a), we find a remarkable reliance on what has gone before: not only do we refine concerns with test consequences or their 'impact' on the basis of traditional distinctions, but we also use standard techniques of empirical analysis, firstly to counter the stigmatisation of individuals whose test results may expose them to that, and, secondly, to promote accountability of design (Weideman \& Van der Slik 2007).

If the continuity in design looks almost inevitable, how does one then progress in language teaching and test designs?
In the next section, I explore a way of potentially enriching our designs by looking across three sets of applied linguistic artefacts.

\section{Reciprocity in design}

If, as the preceding two sections have illustrated, there is continuity in design in the case of both instruction and assessment amidst the incremental changes and advances that are proposed and adopted for each kind of instrument, it appears that there may be a similarity in the conditions for their design. So we should ask: Can the design of one kind of applied linguistic artefact not perhaps be beneficially employed to inform that of another? Would comparisons of these designs not perhaps have reciprocal benefits?

Another set of foundational questions therefore presents itself. How much reciprocity is there in the realms of language testing, language course design, and language policy making? We know, for example, that tests are validated. Two good illustrations of this process of validation in South Africa are Van der Walt and Steyn's (2007) model example of the validation of an undergraduate test of academic literacy, and Van Dyk's (2010) even more comprehensive study. Validity is considered one of the most important considerations in test design (Weideman 2011b). What if we applied that to course design, so that we explicitly check whether the design of a course has been done as responsibly and carefully as a test? Starting with Baretta and Davies's (1985) evaluation of the Bangalore project, the last two decades of the previous century indeed saw many project and programme evaluations (e.g. Kroes 1991a, 1991b; cf. also Alderson \& Baretta 1992; and for South Africa Macdonald \& Burroughs 1991; Kotze \& McKay 1997), yet that has somehow remained limited mainly to the evaluation of donorfunded interventions. The one institutional exception is the evaluation by external panels of experts of not only language courses, but also of the organisational functioning of the subinstitutional units that present them, which may yield some, but never comprehensive information on the validity of their course designs. Yet academic and scholarly discussions even of these larger scale overview assessments (e.g. Weideman $2003 \mathrm{~b}$ ) are rare. Taking a leaf out of the test designers' book, and as professional applied linguists, we need to take our course design tasks much more seriously.

In the same way, one might ask what test designers can learn from course developers. Even conventionally general courses of language ability, such as first and additional languages at secondary school level (cf. DBE 2011a, 2011b), reveal a great deal of specificity, as is currently fashionable. The English First Additional Language and Home Language syllabi emphasise language use for a range of lingual spheres: aesthetic appreciation, through the study of literature, as well as using the language for business, academic, professional and social purposes. This is not yet adequately reflected either in the teaching for the upper secondary school, or in the final exit examination, as a recent report to Umalusi on the assessment of home languages makes clear (Du Plessis, 
Steyn \& Weideman 2013). The point is, however, that language testing in South Africa remains general, and has much to learn from those who design courses for developing language for specific purposes, or within specialised fields. Within the academic world, for example, a language test that is geared towards the assessment of language competence in a specific discipline or field (financial planning, or nursing, or disaster management, to name but three) would be more attractive to their prospective users than a generic test of academic literacy.

This reciprocity is not limited to language tests or language courses. We could just as well ask: How can we learn more from language policy making about providing tests that are more accessible and accountable? If there is any lesson to be learned from failed language policies, plans and strategies, such as those at some nominally multilingual South African universities, it must be that there must be sufficient participation by those who will be affected, which in turn means that the accessibility of information and the accountability of the language management solution proposed are crucial. Thus test designers will do well to make available as much information as is humanly possible on the instruments they develop, as well as to remain open to enquiry and discussion, not despite their technical expertise, but because they have made accountability a part of their professional approach.

It appears that there are many useful questions that we never seem to ask, but the examples I have given here provide a concrete way of promoting at least incremental innovation in our language teaching and testing efforts. Apart from these concrete comparisons (What can the design of artefact $x$ teach us about the design of artefact $y$ ?), there are also more abstract considerations, when we ask the foundational question: How do we conceptualise applied linguistic design principles? The subsequent discussion links strongly to the preceding, since, if the argument is that there is continuity (and mutuality) in design amongst language courses, language tests and language policies, it might reasonably be argued that their design principles may show that same commonality.

\section{A framework of design principles for applied linguistics}

In several recent articles (Weideman 2012, 2013b) I have attempted to articulate what I consider to be a framework of design principles for applied linguistics. At least one (Weideman 2012; but cf. also 2009a, 2011b) refers specifically to principles of language test design. These are derived, for that article, from an idea that conceptualises applied linguistics as a design discipline, which examines two terminal functions of applied linguistic artefacts, their qualifying and their foundational function (see Figure 3).

If the argument that design principles are common across different kinds of applied linguistic designs (language courses, language tests and language plans) is correct, this means that conceptually one should focus on the relationship between the two critical (foundational and qualifying) functions, considering especially the principles that emanate from the technical function of designing, shaping, forming or planning. In the connections that the technical aspect of reality has with all other dimensions, we potentially find the normative moments that might serve as applied linguistic design principles.

In its examination of the technical dimension of experience, a foundational perspective presents us with both constitutive technical concepts and regulative linguistic ideas. These emanate from the connections amongst the technical aspect and every other dimension of reality. Thus the connection between each of the constitutive concepts expresses the analogical conceptual link between each of the preceding aspects with the technical. The numerical analogy may be articulated as a technical systematicity, that is, a unity within a multiplicity of technical norms (conditions for making a design) and technical facts (the actual designed artefacts, be they tests, courses or plans). The spatial link lies in the conceptualisation of the limits of the artefact and what it can accomplish, or the technical range of, for example, its measurement of language ability in the case of a language test. An academic literacy test cannot measure proficiency to deliver a sermon, for example: its range is limited to testing ability within a specified sphere. The technical consistency or reliability of the instrument clearly echoes the link between the technical and the kinematic dimensions of reality, whilst the notion of technical validity derives, in turn, from the link between the technical sphere and the physical (Van Dyk 2010). Similarly, there are connections between the technical and the biotic, sensitive and logical aspects of experience, and these respectively yield the concepts of technical differentiation, appeal and rationality. In disclosing the leading technical function of the design, we find ideas relating to its articulation in the form of a blueprint or set of specifications (the anticipation of the lingual mode), its implementation in interaction with end users (the social anticipation), its technical utility (its analogical link with the economic dimension),

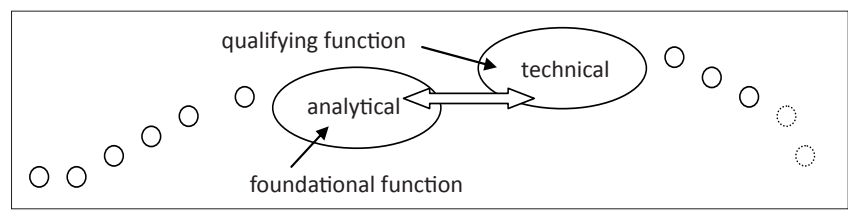

Source: Weideman, A., 2009a, 'Constitutive and regulative conditions for the assessment of academic literacy', Southern African Linguistics and Applied Language Studies 27(3), p. 244 FIGURE 3: Terminal functions of an applied linguistic design.

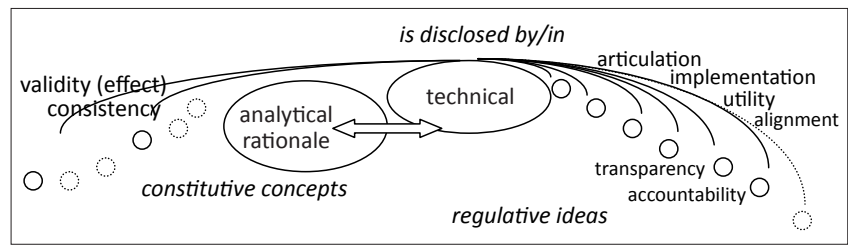

Source: Weideman, A., 2006, 'A systematically significant episode in applied linguistics', in L.O.K. Lategan, \& J.H. Smit (eds.), Time and context relevant philosophy, Journal for Christian Scholarship 42, November, p. 241

FIGURE 4: The disclosure of the leading technical function of an applied linguistic design. 
the technical alignment of the design with the needs of the language learner (an aesthetic moment), its transparency and accountability (that echo the juridical), and also its fairness (the way that the leading technical design function connects with the ethical; cf. Rambiritch 2012). Figure 4 shows some of these constitutive concepts and regulative ideas.

We may summarise the same analysis in Table 1.

From each of these analogical technical concepts emanates a normative appeal: Each potentially yields, as I have outlined in Weideman (2012), a normative moment that provides a condition for the design of what I now believe is any applied linguistic artefact. In the formulations below, I therefore attempt to articulate these design conditions as a set of technically stamped design principles for language tests and language courses, whilst proposing that they may, with the necessary changes, also be applicable to language management policies and plans:

- Systematically integrate multiple sets of evidence in arguing for the validity of the test or course design.

- Specify clearly and to the users of the design, and where possible to the public, the appropriately limited scope of the instrument or the intervention and exercise humility in doing so.

- Ensure that the measurements obtained and the instructional opportunities envisaged are adequately consistent.

- Ensure effective measurement or instruction by using defensibly adequate instruments or material.

- Have an appropriately and adequately differentiated course or test.

- Make the course or the test intuitively appealing and acceptable.

- Mount a theoretical defence of what is taught and tested in the most current terms.

- Make sure that the test yields interpretable and meaningful results, and that the course is intelligible and clear in all respects.

- Make not only the course or the test, but information about them, accessible to as many as are affected by them.
- Present the course and obtain the test results efficiently and ensure that both are useful.

- Mutually align the test with the instruction that will either follow or precede it, and both test and instruction as closely as possible with the learning.

- Be prepared to give account to the users as well as to the public of how the test has been used, or what the course is likely to accomplish.

- Value the integrity of the test and the course; make no compromises of quality that will undermine their status as instruments that are fair to everyone, and that have been designed with care and love.

- Spare no effort to make the course and the test appropriately trustworthy and reputable.

This conceptual framework and the design principles that emanate from it do not lead us towards innovation, but show us that the origin of innovation lies in the first instance in the guiding technical fantasy and imagination of the applied linguist, rather than in the foundational analytical function of the course or test, important as that might be for giving a subsequent rational justification for the imaginative design of the applied linguistic solution that is proposed (Weideman 2006). The framework proposed here has the further purpose of allowing us to assess the relative merits of new developments in design, by providing the broad conceptual outlines (differentiation, consistency, validity, utility, accountability, reputability, and so forth) of the principles that might potentially underlie them. In turn, the concepts and ideas within this framework make it possible for us to assess the blind spots of innovations; the overreliance on rational justification of audio-lingualism, for example, which is the source of its accompanying modernist hubris. We would do well to remember that each new design fashion may have its weak spots. As Lillis (2003) has pointed out, the blind spot of critical, postmodernist approaches is that they do not possess enough follow through from critical analyses to the point that they affect the designed solutions. In short, according to her critique, revolutionary as their political intent may have been, critical approaches are weak on the design side. Though it is much too early to say, one

TABLE 1: Constitutive and regulative moments in applied linguistic designs.

\begin{tabular}{llll}
\hline Applied linguistic design & Aspect/function/dimension/mode of experience & Kind of function & Retrocipatory or anticipatory analogical moment \\
\hline Is founded upon & Numerical & - & Systematicity \\
& Spatial & Limits, range & Internal consistency (technical reliability) \\
& Kinematic & Internal effect or force (validity) & Differentiation \\
& Physical & Constitutive & Intuitive appeal (face validity) \\
& Biotic & - & Design rationale \\
Sensitive & Analytical & - & - \\
Is disclosed by & Technical & Foundational & Articulation of design in a blueprint or curriculum or plan \\
& Lingual & Qualifying/leading function & Implementation or administration \\
& Social & (of the design) & Technical utility, frugality \\
& Economic & - & Harmonisation of conflicts, resolving misalignment \\
& Aesthetic & - & Transparency, defensibility, fairness, legitimacy \\
& Juridical & - & Accountability, care, service \\
& Ethical & Regulative & Reputability and trust
\end{tabular}


may speculate that the emphasis on dynamic change that is characteristic of the paradigm (a dynamic systems approach) that in many important respects is beginning to replace postmodernism, has its risks. If change becomes the only principle, then differentiation and change in design may become the norm (Weideman 2009b, 2013a) to the possible exclusion of other principles.

\section{Conclusion}

Our hope, of course, remains that we might be surprised by innovation in the designed solutions that our profession provides. This article has suggested that we may continue to expect this, but it is more likely to happen in an incremental than in a spectacular fashion. How to evaluate what is offered and paraded as new is therefore more important. In order to accomplish such an assessment of the new, we should also work on our understanding of what constitutes a responsible design framework. At least, then, that might give us a foundation from which to evaluate both the fleeting and the enduring in the new.

\section{Acknowledgments Competing interests}

The author declares that he has no financial or personal relationship(s) that may have inappropriately influenced him in writing this article.

\section{References}

Alderson, J.C. \& Baretta, A. (eds.), 1992, Evaluating second language education Cambridge University Press, Cambridge. http://dx.doi.org/10.1017/ CBO9781139524575, PMCid:PMC1376254

Bachman, L.F. \& A.S. Palmer, 1996, Language testing in practice: Designing and developing useful language tests, Oxford University Press, Oxford. PMCid:PMC39109

Baretta, A. \& Davies, A., 1985, 'Evaluation of the Bangalore project', English Language Teaching Journal 39(2), 121-127. http://dx.doi.org/10.1093/elt/39.2.121

Bell, D.M., 2003, 'Method and postmethod: Are they really so incompatible?', TESOL Quarterly 37(2), 325-336. http://dx.doi.org/10.2307/3588507

Carroll, J.B., 1971, 'Current issues in psycholinguistics and second language teaching', TESOL Quarterly 5, 101-114. http://dx.doi.org/10.2307/3585992

Cope, B. \& Kalantzis, M., 2000, 'Designs for social futures', in B. Cope \& M. Kalantzis (eds.), Multiliteracies: Literacy learning and the design of social futures, pp. 203234, Routledge, London.

Corder, S.P., 1972, 'Problems and solutions in applied linguistics', in J. Qvistgaard, H. Schwarz \& H. Spang-Hanssen (eds.), Applied linguistics: Problems and solutions, vol. III of the Association Internationale de Linguistique Applique Third Congress, Copenhagen, pp. 1-23, Julius Groos Verlag, Heidelberg.

Davies, A., \& Elder, C. (eds.), 2004, The handbook of applied linguistics, Blackwell, Oxford. http://dx.doi.org/10.1002/9780470757000

Department of Basic Education, 2011a, Curriculum and assessment policy statement (CAPS) for English Home Language, Further Education and Training phase, grades 10-12, Department of Basic Education, Pretoria.

Department of Basic Education, 2011b, Curriculum and assessment policy statement (CAPS) for English First Additional Language, Further Education and Training phase, grades 10-12, Department of Basic Education, Pretoria.

Du Plessis, C., Steyn, S. \& Weideman, A., 2013, 'Towards a construct for assessing high level language ability in grade 12 ', preliminary report to the Umalusi Research Forum, ICELDA, Bloemfontein, 13 March.

Fries, C.C., 1945, 'On learning a foreign language as an adult', reprinted in F. Smolinsky (ed.), Landmarks of American language \& linguistics, pp. 51-59, United States Information Agency, Washington.

Greene, R.L., 2012, 'Cultural revolutions', in D. Franklin \& J. Andrews (eds.), Megachange: The world in 2050, pp. 63-76, Profile Books, London.

'Has the ideas machine broken down?', The Economist, 12 January, 2013, p. 19-22.

Heugh, K., 2013, 'Where "whole language" literacy and "communicative" language teaching fail', HSRC Review 11(1), 14-15.
Inter-Institutional Centre for Language Development and Assessment (ICELDA), 2013, Language test development and research, viewed 10 April 2012, from http:// icelda.sun.ac.za

Karavas-Doukas, E., 1996, 'Using attitude scales to investigate teachers' attitudes to the communicative approach', ELT Journal 50(3), 187-198. http://dx.doi. org/10.1093/elt/50.3.187

Kotze, H. \& McKay, V., 1997, Molteno early literacy and language development project evaluation report, ABET Institute, UNISA, Pretoria.

Krashen, S.D. \& Terrell, T.D., 1983, The natural approach: Language acquisition in the classroom, Pergamon/Alemany, Oxford/San Francisco.

Kroes, H., 1991a, Evaluation of the easing into English project, Urban Foundation, Bloemfontein. PMCid:PMC51759

Kroes, H., 1991b, 'Die evaluering van taalonderrig: 'n Voorbeeld uit die praktyk', Journal for Language Teaching 25(3), 30-40.

Kumaravadivelu, B., 2003, Beyond methods: Macrostrategies for language teaching, Yale University Press, London.

Kumaravadivelu, B., 2006, 'Applied linguistics in the age of globalization', in L.P. Moita Lopes (ed.), New ways of doing applied linguistics/Por uma linguistica aplicada indisciplinar, pp. 129-148, Parabola Editorial, Sao Paulo.

Lado, R., 1964, Language teaching: A scientific approach, McGraw-Hill, New York. PMid:14198969

Lamendella, J.T., 1979, The neurofunctional basis of pattern practice, TESOL Quarterly 13(1), 5-19. http://dx.doi.org/10.2307/3585971

Lillis, T., 2003, 'Student writing as "academic literacies": Drawing on Bakhtin to move from critique to design', Language and Education 17(3), 192-207. http://dx.doi. org/10.1080/09500780308666848

Macdonald, C. \& Burroughs, E., 1991, Eager to talk and learn and think: Bilingual primary education in South Africa, Maskew Miller Longman, Cape Town.

Pennycook, A., 1989, 'The concept of method, interested knowledge, and the politics of language teaching', TESOL Quarterly 23(4), 589-618. http://dx.doi. org/10.2307/3587534

Pennycook, A., 1994, 'Critical pedagogical approaches to research', in A. Cumming (ed.), 'Alternatives in TESOL research: Descriptive, interpretive, and ideological orientations', TESOL Quarterly 28(4), 690-693.

Pennycook, A., 1999, 'Introduction: Critical approaches to TESOL', TESOL Quarterly (Special topic issue: Critical approaches in TESOL) 33(3), 329-348.

Pennycook, A., 2004, 'Critical applied linguistics', in A. Davies \& C. Elder (eds.), The handbook of applied linguistics, pp. 784-807, Blackwell, Oxford. http://dx.doi. org/10.1002/9780470757000.ch32

Rambiritch, A., 2012, 'Transparency, accessibility and accountability as regulative conditions for a postgraduate test of academic literacy', PhD thesis, Dept. of English, University of the Free State.

Shenkar, O., 2010, 'Imitation is more valuable than innovation', Reprint F1004F from Harvard Business Review, April, 1-3.

Schumpeter (Blog), 'Pretty profitable parrots', The Economist, 12 May, 2012, p. 60.

Smolinski, F. (ed.), 1985, Landmarks of American language \& linguistics, United States Information Agency, Washington.

Stevick, E.W., 1971, Adapting and writing language lessons, Foreign Service Institute, Washington.

Stevick, E.W., 1980, Teaching languages: A way and ways, Newbury House, Rowley, Massachusetts.

Van der Walt, J.L. \& Steyn, H.S. Jr., 2007, 'Pragmatic validation of a test of academic literacy at tertiary level', Ensovoort 11(2), 138-153.

Van Dyk, T., 2010, 'Konstitutiewe voorwaardes vir die ontwerp van 'n toets van akademiese geletterdheid', PhD thesis, Dept. of English, University of the Free State.

Van Dyk, T. \& Weideman, A., 2004, 'Finding the right measure: From blueprint to specification to item type', SAALT Journal for Language Teaching 38(1), 15-24.

Weideman, A., 2001, 'The old and the new: Reconsidering eclecticism in language teaching', Per Linguam 17(1), 1-13.

Weideman, A., 2002a, 'Overcoming resistance to innovation: Suggestions for encouraging change in language teaching', Per Linguam 18(1), 27-40.

Weideman, A., 2002b, Designing language teaching: On becoming a reflective professional, Business Enterprises at the University of Pretoria, Pretoria.

Weideman, A., 2003a, 'Towards accountability: A point of orientation for post-modern applied linguistics in the third millennium', Literator 24(1), 1-20. http://dx.doi. org/10.4102/lit.v24i1.282

Weideman, A., 2003b, 'Assessing and developing academic literacy', Per Linguam $19(1 / 2), 55-65$.

Weideman, A., 2006, 'A systematically significant episode in applied linguistics', in L.O.K. Lategan, \& J.H. Smit (eds.), Time and context relevant philosophy, Journal for Christian Scholarship 42, November, pp. 231-244.

Weideman, A., 2009a, 'Constitutive and regulative conditions for the assessment of academic literacy', Southern African Linguistics and Applied Language Studies 27(3), 235-251.

Weideman, A., 2009b, 'Uncharted territory: A complex systems approach as an emerging paradigm in applied linguistics', Per Linguam 25(1), 61-75.

Weideman, A., 2011a, A framework for the study of linguistics, Van Schaik/Paideia Press, Pretoria/Grand Rapids. 
Weideman, A., 2011b, 'Academic literacy tests: Design, development, piloting and refinement', SAALT Journal of Language Teaching 45(2), 100-113.

Weideman, A., 2012, 'Validation and validity beyond Messick', Per Linguam 28(2), 1-14.

Weideman, A., 2013a, 'Positivism and postpositivism in applied linguistics, and beyond', in C.A. Chapelle (ed.), The encyclopedia of applied linguistics, WileyBlackwell, Oxford, vol. 7, pp. 4479-4485.

Weideman, A., 2013b, 'Academic literacy interventions: What are we not yet doing, or not yet doing right', Journal for Language Teaching 47(2), 11-23. http://dx.doi. org/10.4314/jlt.v47i2.1.

Weideman, A., 2013c, 'Applied linguistics beyond postmodernism', Acta Academia 45(4), 236-255.
Weideman, A. \& Rousseau, M., 1996, Starting English, Centaur/Heinemann in association with L-MAP, Johannesburg.

Weideman, A., Tesfamariam, H. \& Shaalukeni, L., 2003, 'Resistance to change in language teaching: Some African case studies', Southern African Linguistics and Applied Language Studies 21(1/2), 67-76. http://dx.doi Linguistics and Applied Language
org/10.2989/16073610309486329

Weideman, A. \& Van der Slik, F., 2007, 'The stability of test design: Measuring difference in performance across several administrations of a test of academic difference in performance acto 1 , $161-182$.
literacta

Weideman, A. \& Van Dyk, T. (eds.), (in press), Academic literacy: Test your competence. (Forthcoming from ICELDA) 